\title{
Stress responses of juvenile matrinxã (Brycon amazonicus) after transport in a closed system under different loading densities
}

\author{
Respostas de estresse de matrinxã (Brycon amazonicus) juvenil após transporte em \\ sistema fechado sob diferentes densidades de carga
}

\author{
Janessa Sampaio de Abreu ${ }^{\mathrm{I}}$ Ana Isabel Sanabria-Ochoa' ${ }^{\mathrm{II}}$ Flávio Daolio Gonçalves ${ }^{\mathrm{I}}$ \\ Elisabeth Criscuolo Urbinati ${ }^{\mathrm{I}, \mathrm{II}}{ }^{*}$
}

\begin{abstract}
Optimum loading density for the transport of matrinxã juveniles was investigated in a closed system with plastic bags. Transport was conducted for $4 \mathrm{~h}$ with fish (23.5 \pm $0.4 \mathrm{~g}$ and $11.6(0.08 \mathrm{~cm})$ starved for $24 \mathrm{~h}$ at loading densities of $83 g L^{-1}$ (D1), $125 \mathrm{~g} \mathrm{~L}^{-1}$ (D2), $168 g \mathrm{~L}^{-1}$ (D3) and 206g $\mathrm{L}^{-1}$ (D4). Fish were sampled before transport (BT), after transport (AT) and $24 \mathrm{~h}$ AT. The water quality was monitored before capturing fish in depuration tanks, after transport in plastic bags and in recovery tanks. Water oxygen decreased to values below $4 \mathrm{mg} \mathrm{L}^{-1}$ in D2, D3 and D4, temperature was around $32^{\circ} \mathrm{C}, \mathrm{pH}$ 6.5-6.78, total ammonia $1.09-1.7 \mathrm{mg} \mathrm{L}^{-1}$, un-ionized ammonia 3.58$9.33 \times 103 \mathrm{mg} \mathrm{L}^{-1}$ and alkalinity $134-165 \mathrm{mg} \mathrm{CaCO} \mathrm{L}^{-1}$. Blood cortisol and glucose concentrations increased in fish of all densities AT and recovered the BT levels $24 \mathrm{~h}$ after arrival. Osmolality did not change AT but increased $24 \mathrm{~h}$ AT in fish of all densities whereas plasma chloride decreased inversely to the loading densities after the procedure. Hematocrit decreased $24 \mathrm{~h} A \mathrm{~T}$ in fish of all densities but no differences were verified in the number of erythrocytes. No mortality was registered in any treatment during the next week after transport. Matrinxã demonstrated to be a crowding tolerant-species in transport operations besides tolerating low levels of oxygen in the water.
\end{abstract}

Key words: stress, fish density, transport, water quality, Brycon amazonicus.

\section{RESUMO}

Neste estudo, foram investigadas as densidades de carga adequadas para transporte de matrinxãs juvenis em sistema fechado com sacos plásticos. O transporte de 4 h foi feito com peixes $(23,5 \pm 0,4 \mathrm{~g} ; 11,6(0,08 \mathrm{~cm})$ em jejum por $24 \mathrm{~h}$, em densidades de $83 g L^{-1}$ (D1), $125 g L^{-1}$ (D2), $168 g L^{-1}$ (D3) $e$ $206 \mathrm{~g} \mathrm{~L}^{-1}$ (D4). Os peixes foram amostrados antes do transporte (AT), logo após o transporte (chegada) (DT) e 24h depois. A qualidade da água foi monitorada antes da captura dos peixes nos tanques de depuração, após o transporte nos sacos plásticos e nos tanques de recuperação. $O$ oxigênio da água diminuiu para valores inferiores a $4 \mathrm{mg} \mathrm{L}^{-1} \mathrm{em} \mathrm{D2,} \mathrm{D3} \mathrm{e} \mathrm{D4,} \mathrm{a} \mathrm{temperatura}$ esteve em torno de $32^{\circ} \mathrm{C}$, pH 6,5-6,78, a amônia total foi de 1,09-1,7mg $L^{-1}$, a amônia não-ionizada foi de 3,58-9,33 x

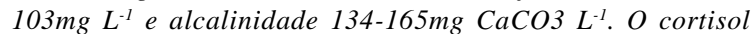
plasmático e a glicose sanguínea aumentaram após o transporte nos peixes em todas as densidades ensaiadas, voltando aos valores controle $24 \mathrm{~h}$ depois. Os valores de osmolaridade não mudaram logo após o transporte, mas aumentaram $24 \mathrm{~h}$ depois de modo igual em todas as densidades. O cloreto plasmático diminuiu na chegada, de modo inversamente proporcional à densidade de carga. O hematócrito diminuiu $24 \mathrm{~h}$ depois da chegada dos peixes, em todas as densidades testadas, mas não houve diferença no número de eritrócitos. Não houve mortalidade até uma semana após o transporte. O matrinxã mostrou ser uma espécie tolerante a altas densidades de carga em embalagens para transporte além de suportar baixos níveis de oxigênio na água.

Palavras-chave: estresse, densidade, transporte, qualidade da água, Brycon amazonicus.

\section{INTRODUCTION}

Aquaculture has been rapidly expanding in Brazil and farming practices are now being examined to assess their impact on the production and animal welfare. Juvenile fish transportation is an important issue in fish farming and it generally imposes severe stress to fish (IVERSEN et al., 1998). Handling and transport may promote hormonal, metabolic,

\footnotetext{
ICentro de Aqüicultura, Universidade Estadual Paulista (CAUNESP). Jaboticabal, SP, Brasil.

IIInstituto Colombiano de Desenvolvimento Rural (INCODER).

IIIFaculdade de Ciências Agrárias e Veterinárias (FCAV), Universidade Estadual Paulista (UNESP). Via de Acesso Prof. Paulo Donato Castelane, 14884-900, Jaboticabal, SP, Brasil. Fone: (0xx55)3209 2654. Fax: (0xx55) 3203 2268. E-mail: bethurb@caunesp.unesp.br. *Autor para correspondência.
} 
osmoregulatory and hematological dysfunctions in fish (WENDELAAR BONGA, 1997). Monitoring physiological parameters during transport can provide data for the establishment of appropriate management techniques. Blood glucose and cortisol are useful stress indicators (MORGAN \& IWAMA, 1997). Additionally, altered ionic balance in blood occurs during stressful situations (CARMICHAEL et al., 1984; McDONALD \& MILLIGAN, 1997) and the hematological status can also change by transporting fish (CARMICHAEL, 1984). Appropriate shipment conditions may minimize stress during transport whereas high fish density is important for reducing the costs. High packing density leads to stressing factors such as mechanical abrasion among fish (ROSS \& ROSS, 1999), social interaction (ALANÄRÄ \& BRÄNNÄS, 1996) and water quality deterioration (MEADE et al., 1985; PICKERING \& POTTINGER, 1987).

Matrinxã, Brycon amazonicus (SPIX \& AGASSIZ, 1829), a native species of the Amazon Basin, has been raised in many regions of Brazil and research on farming management and stress physiology of the species is still scarce (CARNEIRO \& URBINATI, 2001; IDE et al., 2003; ROCHA et al., 2004; URBINATI et al., 2004). The aim of this study was to find the maximal packing density to be used in commercial transport of juvenile fish in closed systems through their physiological responses.

\section{MATERIAL AND METHODS}

Fish (23.5 $\pm 0.4 \mathrm{~g} ; 11.6 \pm 0.08 \mathrm{~cm})$ were allocated in four depuration 1000L tanks with continuous water and air flow (143 fish for tank), and fasted for 24h prior to transport. Before transport (BT) 24 fish were sampled and pooled (3 fish) because of their small size making $\mathrm{n}=8$. Fish were then packed in $30 \mathrm{~L}$ plastic bags, at $83 \mathrm{~g}$ $\mathrm{L}^{-1}$ (D1), 125g L-1 (D2), 168g L $\mathrm{L}^{-1}$ (D3) and 206g L-1 (D4) (4 bags per density). Densities were determined based in those usually used in local hatcheries, between 83 and $125 \mathrm{~g} \mathrm{~L}^{-1}$. Within four minutes, individual bags containing fish were inflated with oxygen (around 2/3) and tied tightly. Four bags of each density were packed in styrofoam boxes displaced on a pickup truck. After a 4h transport (AT) fish were sampled (6 from each replicate bag, 24 for density, $\mathrm{n}=8$ ) and the remainders were transferred to four recovery tanks (one per density) where they were maintained for an extra week. Additional samplings were carried out at 24h AT (24 fish for density, $n=8$ ). Fish were not fed until the $24 \mathrm{~h}$ sampling. Water quality was monitored in the depuration tanks after the $4 \mathrm{~h}$ transportation in the bags and $24 \mathrm{~h}$ after transport in the recovery tanks through temperature and dissolved oxygen measurement (YSI
55 oxygen meter and YSI 63 pH meter, (Yellow Springs Instruments, Yellow Springs, Ohio, USA), total ammonia (SOLÓRZANO, 1969) and alkalinity (GOLTERMAN et al., 1978) determination. Un-ionized ammonia was calculated according to EMERSON et al. (1975).

Benzocaine anesthetized fish (50mg L $\mathrm{m}^{-1}$ ) were bled and samples of heparinized blood were used for glucose analyses (KING \& GARNER, 1947), hematocrit determination and erythrocyte counting (Neubauer chamber). After blood centrifugation (3,000 rpm, 10min) separated plasma was used for cortisol (Radioimunoassay - Kit Diagnostics Products Corporation), chloride (Kit Labtest Diagnóstica) and osmolality (Osmometer Wescor Model 505) analysis.

A completely randomized design (CRD) was employed and results were analyzed by a two-way analysis of variance, with densities (83, 125, 168 and 206 L $\mathrm{g}^{-1}$ ) and sampling times (after transport and 24h after transport) as the factors plus the pre-transport condition (BT). When F values indicated significance $(\mathrm{P}<0.05)$ means were compared by the Tukey test.

\section{RESULTS}

The data obtained on water quality parameters (temperature, $\mathrm{pH}$, dissolved oxygen, total ammonia, un-ionized ammonia and alkalinity) are presented in the table 1 . No fish mortality was registered in any treatment throughout the week following the transport. Plasma cortisol and blood glucose levels increased in fish for all densities analyzed at arrival (AT) and returned to the initial conditions in 24h. Plasma osmolality values did not changed AT but increased 24h after the procedure in fish for all densities analyzed. Plasma chloride concentrations decreased inversely to the densities AT and were lower than the control levels registered BT. Hematocrit decreased 24h AT in fish of all densities treatments but no changes were found in erythrocyte counts (Figure 1).

\section{DISCUSSION}

The extent of the stress of matrinxã was determined under different loading densities during a 4h-transport in a closed system. The elevation of circulating cortisol is a primary stress response whereas plasma glucose is a secondary response that provides energy for the fish to withstand the adverse condition (WENDELAAR BONGA, 1997). According to these indicators transported matrinxã were affected by the procedure. Plasma cortisol and blood glucose increased in a similar fashion in fish of all densities suggesting that stress was elicited at the same degree in all loading densities. The stress response was elicited by the transport operation and not by the crowding in the 
Table 1 - Water temperature, $\mathrm{pH}$, dissolved oxygen, total ammonia, un-ionized ammonia and alkalinity before transport (BT), after transport (AT) and 24h after transport. D1 - 83g L ${ }^{-1}$; D2 - 125g L ${ }^{-1}$; D3 - 168g L ${ }^{-1}$; $44-206 \mathrm{~g} \mathrm{~L}^{-1}$.

\begin{tabular}{|c|c|c|c|c|c|}
\hline & & D1 & D2 & D3 & D4 \\
\hline \multirow{3}{*}{ Temperature $\left({ }^{\circ} \mathrm{C}\right)$} & BT & 26.7 & 26.1 & 26.9 & 27.3 \\
\hline & $\mathrm{AT}$ & $31.6 \pm 0.24$ & $32.0 \pm 0.29$ & $32.3 \pm 0.22$ & $32.0 \pm 0.27$ \\
\hline & $24 \mathrm{~h}$ & 27.8 & 27.8 & 27.8 & 27.8 \\
\hline \multirow{3}{*}{$\mathrm{pH}$} & $\mathrm{BT}$ & 7.3 & 7.3 & 7.3 & 7.3 \\
\hline & $\mathrm{AT}$ & $6.8 \pm 0.10$ & $6.6 \pm 0.05$ & $6.5 \pm 0.04$ & $6.50 \pm 0.03$ \\
\hline & $24 \mathrm{~h}$ & 8.0 & 7.3 & 7.3 & 7.1 \\
\hline \multirow{3}{*}{ Dissolved oxygen $\left(\mathrm{mg} \mathrm{L}^{-1}\right)$} & $\mathrm{BT}$ & 6.3 & 5.7 & 6.3 & 2.6 \\
\hline & $\mathrm{AT}$ & $9.4 \pm 1.23$ & $3.8 \pm 1.59$ & $4.0 \pm 1.20$ & $1.8 \pm 0.25$ \\
\hline & $24 \mathrm{~h}$ & 6.50 & 5.40 & 5.46 & 5.89 \\
\hline \multirow{3}{*}{ Total ammonia (mg L $\left.{ }^{-1}\right)$} & BT & - & - & - & 0.36 \\
\hline & $\mathrm{AT}$ & $1.7 \pm 0.08$ & $1.53 \pm 0.03$ & $1.48 \pm 0.06$ & $1.09 \pm 0.07$ \\
\hline & $24 \mathrm{~h}$ & - & - & - & - \\
\hline \multirow{3}{*}{ Un-ionized ammonia $\left(\mathrm{mg} \mathrm{L}^{-1}\right) \times 10^{-3}$} & $\mathrm{BT}$ & - & - & - & 4.68 \\
\hline & $\mathrm{AT}$ & $9.33 \pm 1.73$ & $6.45 \pm 0.86$ & $4.84 \pm 0.47$ & $3.58 \pm 0.42$ \\
\hline & $24 \mathrm{~h}$ & - & - & - & - \\
\hline \multirow{3}{*}{ Alkalinity $\left(\mathrm{mgCaCO}_{3} \mathrm{~L}^{-1}\right)$} & $\mathrm{BT}$ & 178.0 & 151.2 & 96.8 & 132.0 \\
\hline & AT & $165.6 \pm 12.09$ & $159.40 \pm 17.18$ & $134.30 \pm 12.93$ & $154.35 \pm 10.55$ \\
\hline & $24 \mathrm{~h}$ & 156.4 & 139.4 & 172.2 & 160.0 \\
\hline
\end{tabular}

Empty lines indicate undetected levels of un-ionized ammonia in water. Mean \pm S.E.M.

plastic bags. However, in a previous study with the same species, fish density was inversely related to the cortisol levels (URBINATI et al., 2004). Matrinxã seems to be highly tolerant to crowding conditions as described by ROCHA et al. (2004), who found that matrinxã transferred to a tank at a 4 fold stocking density (350 $\left.\mathrm{L} \mathrm{L}^{-1}\right)$ did not show changes in stress indicators.

Cathecolamines induces increased gill permeability during stress which result in blood electrolytes imbalance (McDONALD \& MILLIGAN, 1997). In our study, chloride levels decreased after transport inversely to fish density, thus confirming stress in transported fish. Adult matrinxã transported in high densities also showed reduction of chloride after the procedure (CARNEIRO \& URBINATI, 2002). The highest values of osmolality were verified $24 \mathrm{~h}$ AT and may be related to the feeding that was normalized at that time. Similar ionic response was reported in other transported fish (CARMICHAEL 1984; BARTON et al., 2003), but a simulation of high-density transport did not cause any serious osmoregulatory disturbance in Atlantic cod (Gadus morhua) until 24h after the stressor (STAURNES et al., 1994).

Alterations in hematocrit and hemoglobin have been observed as a stress response in fish (WOJTASZEK et al., 2002). According to MORGAN \& IWAMA (1997), catecholamines and cortisol promote tissue oxygen consumption and a fast erythrocytes differentiation and proliferation. However, no changes were verified in hematological parameters of matrinxã following the profile of cortisol and glucose.

In closed systems, water quality is an effective precursor of stress and sometimes a limiting factor (BERKA, 1986; ROSS \& ROSS, 1999). Water quality will depend on fish density and transport duration. In closed systems with pressurized oxygen, water oxygen level usually is not the limiting factor, but gas deficit may occur when fish density is high or the transport period is too long (BERKA, 1986). After 4h-transport, levels of water oxygen reached values lower than $4 \mathrm{mg} \mathrm{L}^{-1}$ in the three highest fish densities, values below those recommended for warm water tropical fishes (WEDEMEYER, 1996). However, the low oxygen levels did not seem to affect adversely the matrinxã since no changes in values of stress indicators could be associated to them and no mortality was registered through the week following the transport.

Water $\mathrm{pH}$ is a control factor of water quality because the proportion of toxic ammonia and $\mathrm{CO}_{2}$ level are a direct function of $\mathrm{pH}$, whereas water $\mathrm{pH}$ and temperature can affect ammonia toxicity (BOYD, 1982). With increasing fish density, $\mathrm{CO}_{2}$ production through fish respiration shifts water $\mathrm{pH}$ towards acidity. The $\mathrm{pH}$ around 6.5-6.8 allowed the production of a small amount of $\mathrm{NH}_{3}$ even in the highest fish density. Thus ammonia toxicity was extremely low. Once the levels observed during the experiment were not harmful to juvenile matrinxã and were lower than those 


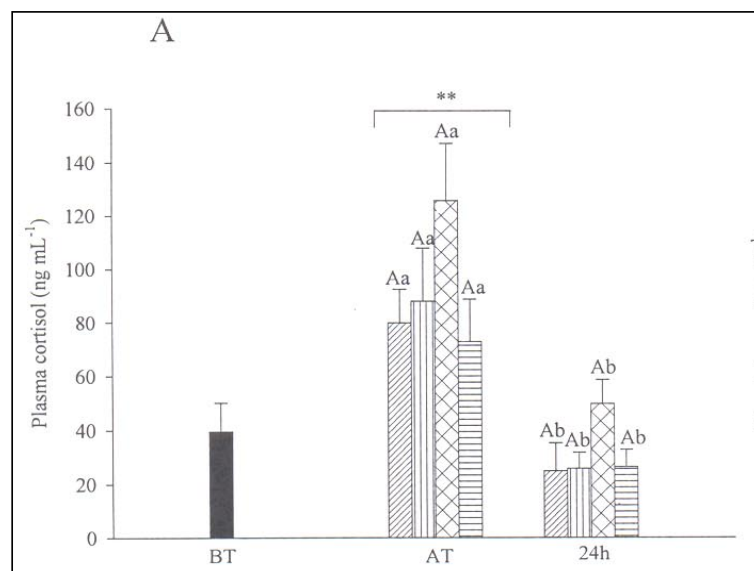

$\mathrm{B}$
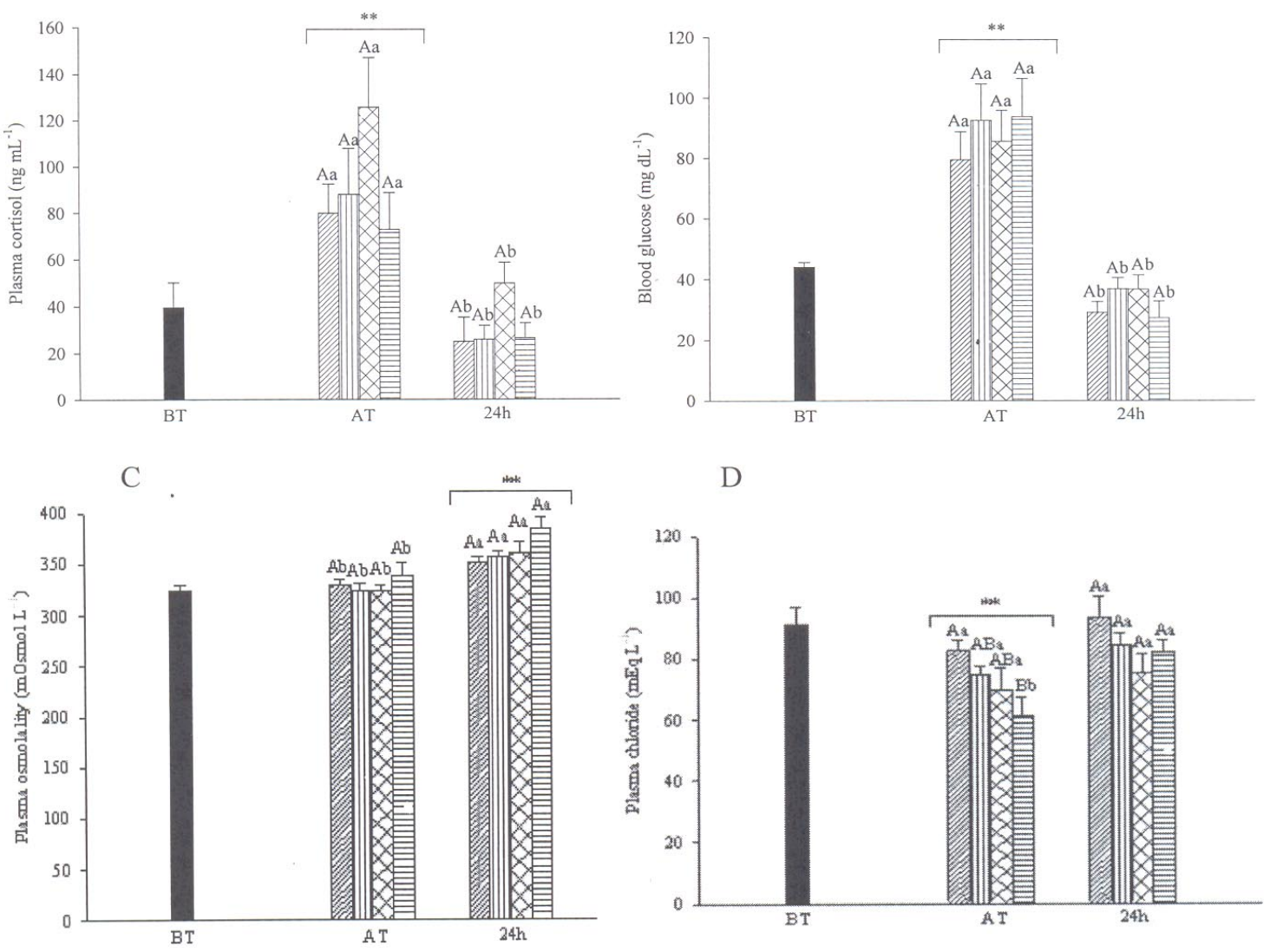

$\mathrm{D}$

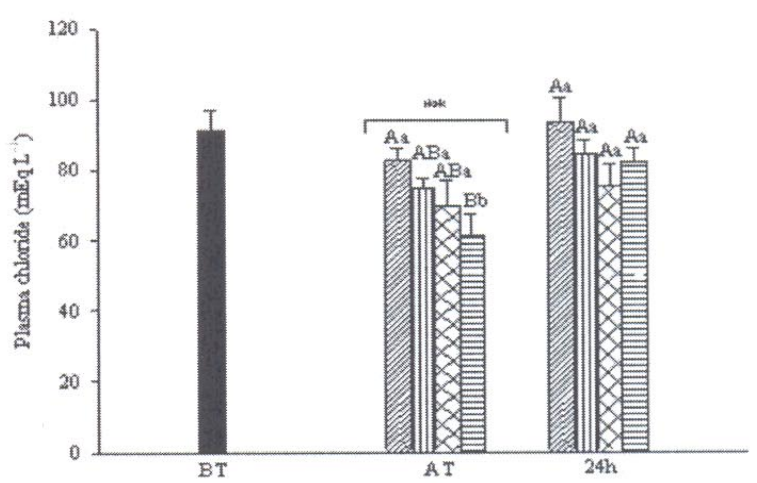

E

$\mathrm{F}$
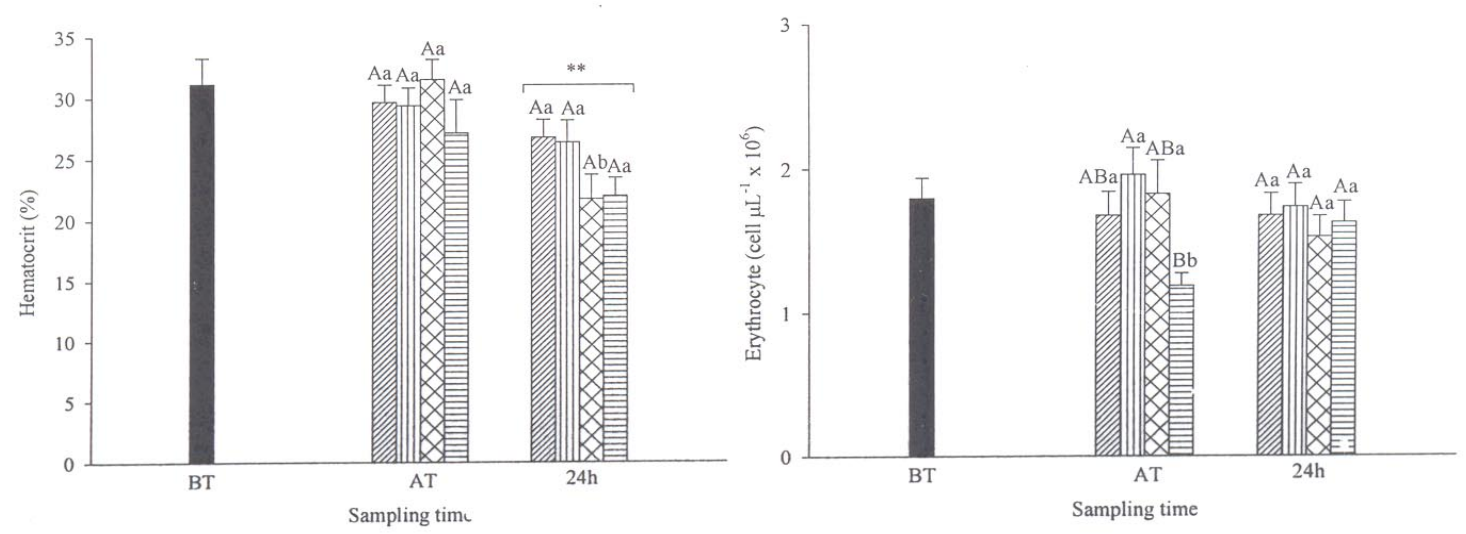

Figure 1 - (A) Plasma cortisol (ng $\mathrm{mL}^{-1}$ ), (B) blood glucose ( $\left.\mathrm{mg} \mathrm{dL}^{-1}\right),(\mathrm{C})$ plasma osmolarity ( $\mathrm{mOsmol} \mathrm{L}^{-1}$ ), (D) plasma chloride (mEq L-1), (E) hematocrit (\%) and (F) erythrocyte number (cell $\mu \mathrm{L}^{-1} \times 10^{6}$ ) of matrinxã transported at:

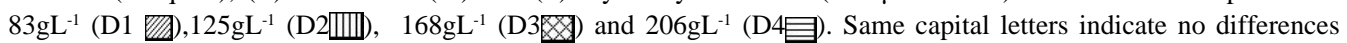
among treatments within sampling times and lower case letters among same treatment in different samplings. ** $(\mathrm{p}<0.01)$ indicate differences between each sampling time and initial level. $\mathrm{BT}$ - before transport (initial level), AT - after transport and 24h after transport.

recommended by WEDEMEYER (1996) to guarantee good health condition for fish $\left(0,02 \mathrm{mg} \mathrm{L}^{-1}\right)$. The $\mathrm{CO}_{2}$ in the water reacts with it to form carbonic acid, a weak acid that will dissociate into bicarbonate and carbonate, depending on the pH levels. They may react with cations, particularly with calcium to form solid carbonates, contributing to water alkalinity. The alkalinity and carbon dioxide are important parameters

Ciência Rural, v.38, n.5, ago, 2008. 
in aquaculture and are often considered as the carbonate buffer system. The bicarbonates and carbonates function like buffers preventing sudden alterations in the $\mathrm{pH}$ that can affect fish (AVAULT Jr., 2004). In this study, the pH decreased after transport, but the change was moderate even in the highest transport densities, showing the buffer effect of alkalinity.

\section{CONCLUSIONS}

The fish crowding during 4h-transport and the changes in water quality were not associated to the stress indicators for matrinxã. Matrinxã demonstrated to be a crowding tolerant-species in transport operation besides to tolerate low levels of oxygen in the water.

\section{REFERENCES}

ALANÄRÄ, A.; BRÄNNÄS, E. Dominance-feeding behavior in Artic charr and rainbow trout: the effect of stocking density. Journal of Fish Biology, v.48, p.242-254, 1996.

AVAULT, JR., J.W. Water management in ponds - Some basics reviewed, part 2. Aquaculture Magazine, v.30, n.5, p.4043, 2004.

BARTON, B.A. et al. Plasma cortisol and chloride stress responses in juveniles walleyes during capture, transport and stocking procedures. North American Journal of Aquaculture, v.65, p.210-219, 2003.

BERKA, R. The transport of live fish. A review. Rome, Italy: FAO, 1986. (EIFAC Tech. Pap. 48).

BOYD, C.E. Water quality management for pond fish culture. Amsterdam, The Netherlands: Elsevier Science, 1982. 317p.

CARMICHAEL, G.J. Long-distance truck transport of intensively reared largemouth bass. Progressive FishCulturist, v.46, n.2, p.111-115, 1984.

CARMICHAEL, G.J. et al. Characterization and alleviation of stress associated with hauling largemouth bass. Transactions of the American Fisheries Society, v.113, p.778-785, 1984.

CARNEIRO, P.C.F.; URBINATI, E.C. Salt as a stress response mitigator of matrinxã Brycon cephalus during transport. Aquaculture Research, v.32, p.297-304, 2001.

CARNEIRO, P.C.F.; URBINATI, E.C. Transport stress in matrinxã, Brycon amazonicus (Teleostei: Characidae), at different densities. Aquaculture International, v.32, p.1-9, 2002.

EMERSON, K. et al. Aqueous ammonia equilibrium calculations: Effect of $\mathrm{pH}$ and temperature. Journal of Fisheries and Resources Board of Canada, v.32, p.2379-2383, 1975.

GOLTERMAN, H.L. et al. Methods for physical and chemical analysis of fresh waters. London: Blackwell Science Publications, 1978. 213p.
IDE, L.M. et al. The role of olfaction in the behavioral and physiological responses to conspecific skin extract in a teleost fish, Brycon cephalus. Journal of Fish Biology, v.63, p.332343, 2003.

IVERSEN, M. et al. Recovery from loading and transport stress in Atlantic salmon (Salmo salar L.) smolts. Aquaculture, v.168, p.387-394, 1998.

KING, E.J.; GARNER, R.J. Colorimetric determination of glucose. Journal of Clinical Pathology, v.1, p.30-33, 1947.

McDONALD, G.; MILLIGAN, L. Ionic, osmotic and acid-base regulation in stress. In: IWAMA, G.W. et al. Fish stress and health in aquaculture. Cambridge, England: Cambridge University, 1997. p.119-144.

MEADE, J.W. et al. Effects of cumulative loading level, as fish weight per unit of flow, on water quality and growth of lake trout. Journal of the World Mariculture Society, v.16, p.40-51, 1985.

MORGAN, J.D.; IWAMA, G.K. Measurements of stressed states in the field. In: IWAMA, G.W. et al. Fish stress and health in aquaculture. Cambridge, England: Cambridge University, 1997. p.247-270.

PICKERING, A.D.; POTTINGER, T.G. Poor water quality suppresses the cortisol response of salmonid fish to handling and confinement. Journal of Veterinary and Biology, v.30, p.363-374 1987.

ROCHA, R.M. et al. Physiological responses associated with capture and crowding stress in matrinxã Brycon cephalus (Gunther, 1869). Aquaculture Research, v.35, p.245-249, 2004.

ROSS, L.G.; ROSS, B. Anesthetic and sedative techniques for aquatic animals. Oxford, UK: Blackwell Science, 1999. $176 \mathrm{p}$.

SOLÓRZANO, L. Determination of ammonia in natural water by the phenol hypochlorite method. Limnology and Oceanography, v.14, p.799-801, 1969.

STAURNES, M. et al. Physiological effects of simulated highdensity transport of Atlantic cod (Gadus morhua). Aquaculture, v.119, p.381-391, 1994.

URBINATI, E.C. et al. Loading and transport stress in juvenile matrinxã (Brycon cephalus) at various densities. Aquaculture, v.229, p.389-400, 2004.

WEDEMEYER, G.A. Physiology of fish in intensive culture systems. New York: Chapman \& Hall, 1996. p.1059

WENDELAAR BONGA, S.E. The stress response in fish. Physiological Reviews, v.77, n.3, p.591-625. 1997.

WOJTASZEK, J. et al. Hematological effects of high dose of cortisol on the carp (Cyprinus carpio L.): cortisol effect on the carp blood. General and Comparative Endocrinology, v.125, p.176-183, 2002. 